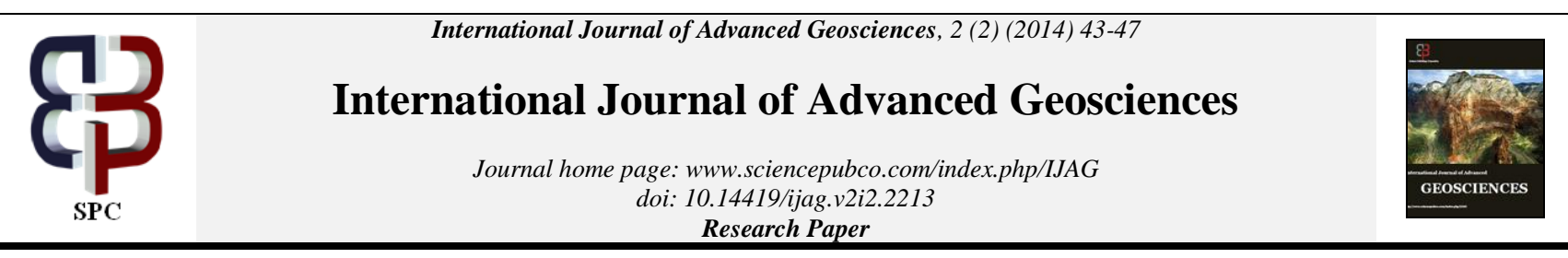

\title{
Mapping of groundwater quality using GIS technique in the east coast of Tamilnadu state and Pondicherry union territory, India
}

\author{
Kumaravel $S^{1}{ }^{*}$, Gurugnanam $B^{2}$, Bagyaraj $M^{1}$, Venkatesan $S^{1}$, Suresh $M^{3}$, Chidambaram $S^{1}$, \\ Jeyavel Rajakumar $T^{1}$; Gnanachandrasamy $\mathbf{G}^{1}$ \\ ${ }^{1}$ Department of Earth Sciences, Annamalai University, Chidambaram, Tamilnadu, India 608002 \\ ${ }^{2}$ Centre for Applied Geology, Gandhi gram Rural Institute (Deemed University), Dindigul \\ ${ }^{3}$ Department of Geology, Periyar University, Salem, Tamilnadu, India - 636011 \\ *Corresponding author E-mail: kumaravel644@yahoo.com
}

\begin{abstract}
The objective of this study is to determine temporal and spatial changes in groundwater quality and sources of contamination. An attempt has been made in the present study to elucidate the quality of the groundwater in terms of physical and chemical parameters in the post and pre monsoon season in the east coast of Tamilnadu state and Pondicherry Union Territory. Geologically, the study area consists of alluvium, Cuddalore sandstone and charnockite. 37 groundwater samples were collected from bore wells and analyzed for $\mathrm{pH}$, TDS, Ca+, $\mathrm{Mg}+, \mathrm{Na}+, \mathrm{K}+, \mathrm{Cl}-, \mathrm{HCO} 3-, \mathrm{SO} 4-$ and F-. The analyzed values were evaluated and compared with World Health Organization (2004) for drinking water. It was observed that, $\mathrm{Ca}+\mathrm{Mg}+, \mathrm{Na}+, \mathrm{K}+, \mathrm{Cl}-, \mathrm{SO} 4-$ and $\mathrm{F}$ - are within the acceptable limit for drinking purposes in both the seasons except few sample locations. To identify the suitable zones of drinking water, overlay analyses were carried out using ArcGIS and classified as good, medium and poor zones for both the seasons. The zone of good quality of the groundwater for post and pre monsoon season in the study area was $118.93 \mathrm{~km} 2$ and $88.39 \mathrm{~km} 2$ respectively.
\end{abstract}

Keywords: Spatial Changes, Groundwater Quality, Chemical Parameters, Drinking Purposes, ArcGIS.

\section{Introduction}

Groundwater is often the most important water resource for drinking, irrigation and industrial purpose in coastal areas (Kim et al., 2003; Leung et al., 2005; Guler et al., 2012; Wang \& Jiao, 2012; Carol et al., 2013). According to Rai (2004), about $80 \%$ of the earth's surface is covered by water yet qualitatively $97 \%$ of this vast natural resource falls unfit for human use. Most of the freshwater bodies are becoming increasingly polluted in the worldwide, thus decreasing the potability of water (Dixit et al., 2005). Gleeson et al., (2012) states that fresh water for life is $0.6 \%$ of the total water budget with the bulk of it tied up in groundwater. Groundwater has strategically remained valuable as the major and preferred source of drinking water because of its naturally high quality and availability in the face of surface water maintenance culture deficiency and regular supply inconsistencies. Water scarcity resulting from increasing demand over the years in different parts of the world has also been aggravated by the problems of water pollution or contamination. Majority of these problems results from improper management of water resources and environmental degradation from natural sources (Olowokudejo 2007).

Growing urbanization, exploding population, and intensive agriculture are just some of the contributing factors for groundwater quality deterioration. The knowledge of the occurrence, replenishment and recovery of potable groundwater assumes special significance in quality-deteriorated regions, because of scarce presence of surface water. Todd (1980) states that, the unfavorable climatic condition of low rainfall with frequent occurrence of dry spells, high evaporation, etc. on one hand and an unsuitable geological set up on the other, a definite limit on the effectiveness of surface and subsurface reservoirs. According to Gimenez \& Morell, (1997) and Cruz and Silva (2000), heavy pumping and excessive use of near-coast groundwater have caused rapid depletion of water tables as well as deterioration of water quality in most of the coastal cities. Therefore, it requires protection from the anthropogenic activities to prevent further groundwater contamination.

The objective of this study is to determine temporal and spatial changes in groundwater quality and the relationship between quality parameters and sources of contamination.

\section{Study area}

The area under study is an adjoining area of Marakkanam in the east coast of Tamilnadu State, and Pondicherry Union Territory, India. Geographically, the study area lies between $11^{\circ} 45^{\prime}$ to $12^{0}$ $03^{\prime} \mathrm{N}$ latitude and $77^{\circ} 45^{\prime}$ and $77^{\circ} 50^{\prime} \mathrm{E}$ longitude (Fig 1) and covers an area of $140 \mathrm{~km}^{2}$. Physiographically, the study area is flat plain with an average elevation of about $15 \mathrm{~m}$ above MSL (CGWB, 1993). The climate is humid and tropical. The mean monthly temperature ranges from 22 to 33 degree Celsius and received an annual rainfall of $1281 \mathrm{~mm}$. The position of groundwater table varied from 1.5 to 27 meter. Geologically, the area consists of quaternary, tertiary and Mesozoic sediments of alluvium $\left(136.45 \mathrm{~km}^{2}\right)$, cuddalore sandstone $\left(2.60 \mathrm{~km}^{2}\right)$, and charnockite $\left(0.95 \mathrm{~km}^{2}\right)$ with Archaeans as the basement rocks (CGWB, 1993). 


\section{Methodology}

Samples were collected from water supply sources through production wells, public hand pumps and bore wells. 37 groundwater samples were collected from bore wells and analyzed for components such as physical and chemical parameters of $\mathrm{pH}$, TDS, major cations and anions of $\mathrm{Ca}^{+}, \mathrm{Mg}^{+}, \mathrm{Na}^{+}, \mathrm{K}^{+}, \mathrm{HCO} 3, \mathrm{SO} 4$, and Fluoride $\left(\mathrm{F}^{-}\right)$. In the present study, 37 groundwater samples were collected during the post monsoon (January 2012) and pre monsoon (June 2012). Electrical conductivity (EC) and hydrogen ion concentration $(\mathrm{pH})$ were measured at the field during sampling. The samples were analyzed as per the methods described by APHA (1995), $\mathrm{Ca}^{+}, \mathrm{Mg}^{+}, \mathrm{HCO}^{-}$and $\mathrm{Cl}^{-}$were analyzed by volumetric titration methods, $\mathrm{Na}^{+}$and $\mathrm{K}^{+}$be measured using the flame photometer, $\mathrm{SO}^{-}$and $\mathrm{F}^{-}$were determined by spectro photometric technique. The experimental values were compared to standard values recommended by World Health Organization (WHO 2004) for drinking purposes. The results of physiochemical analysis are presented in table 1.
Base map was prepared from Survey of India Toposheet Nos. 58 $\mathrm{M} / 13$, and 16 on $1: 50,000$ scale. The topographic maps were registered and digitized the sample locations with the help of GPS and linked with hydrogeochemical results in GIS environment. The attributes are added and analyzed in ArcGIS software using spatial analysis tools for the preparation of interpolation using inverse distance methods to achieve the spatial distribution map. Thematic maps were integrated one over the other to find out the area of good groundwater quality zones for both seasons.

\section{Result and discussion}

The $\mathrm{pH}$ level in the groundwater samples varied from 7.50 to 9.02 and 6.75 to 8.12 in the post and pre monsoon during the study period. The minimum value of $\mathrm{pH}$ was observed in the sample no. 15 (7.50 and 6.75) and maximum noticed at the sample no.10 (9.02 and 8.12) during both seasons. Due to dissolved atmospheric carbon dioxide which will release sodium, calcium with turn progressively increased the $\mathrm{pH}$ and alkalinity of the

Table 1: Physicochemical Characteristics of Ground Water during Post and Pre Monsoon Season

\begin{tabular}{|c|c|c|c|c|c|c|}
\hline \multirow{3}{*}{ Sample No. } & \multirow{3}{*}{ Water quality parameter in $\mathrm{mg} / \mathrm{l}$} & \multirow{3}{*}{ WHO standard mg/l (2004) } & \multicolumn{4}{|c|}{ Concentration in the study area $(\mathrm{mg} / \mathrm{l})$} \\
\hline & & & \multicolumn{2}{|c|}{ Post monsoon } & \multicolumn{2}{|l|}{ Pre monsoon } \\
\hline & & & Min & $\operatorname{Max}$ & Min & Max \\
\hline 1 & $\mathrm{pH}$ & 6.5 to 8.5 & 7.5 & 8.89 & 6.75 & 8.12 \\
\hline 2 & TDS & $\begin{array}{c}<500, \\
500-1500,>1500\end{array}$ & 170 & 1148 & 126 & 951 \\
\hline 3 & Calcium (Ca) & $<75,75-200$ & 16 & 143 & 25 & 200 \\
\hline 4 & Magnesium (Mg) & $\begin{array}{c}<30 \\
30-150\end{array}$ & 1 & 97.47 & Below detectable limit & 44 \\
\hline 6 & Potassium (K) & $<10,>10$ & 1 & 21 & 0.1 & 68.9 \\
\hline 7 & Chloride $(\mathrm{Cl})$ & $<250,250-600$ & 81 & 407 & 44.31 & 487.43 \\
\hline 8 & Bicarbonate $\left(\mathrm{HCO}_{3}\right)$ & $<300,300-600$ & 12 & 122 & 58.8 & 549 \\
\hline 9 & Sulphate $\left(\mathrm{SO}_{4}\right)$ & $\begin{array}{l}<200 \\
>200\end{array}$ & 2 & 21.9 & Below detectable limit & 7.1 \\
\hline 10 & Fluoride $(\mathrm{F})$ & $0.5-1.5,>1.5$ & 0.82 & 1.64 & 0.61 & 2.09 \\
\hline
\end{tabular}



Fig. 1: Study Area Location Map 


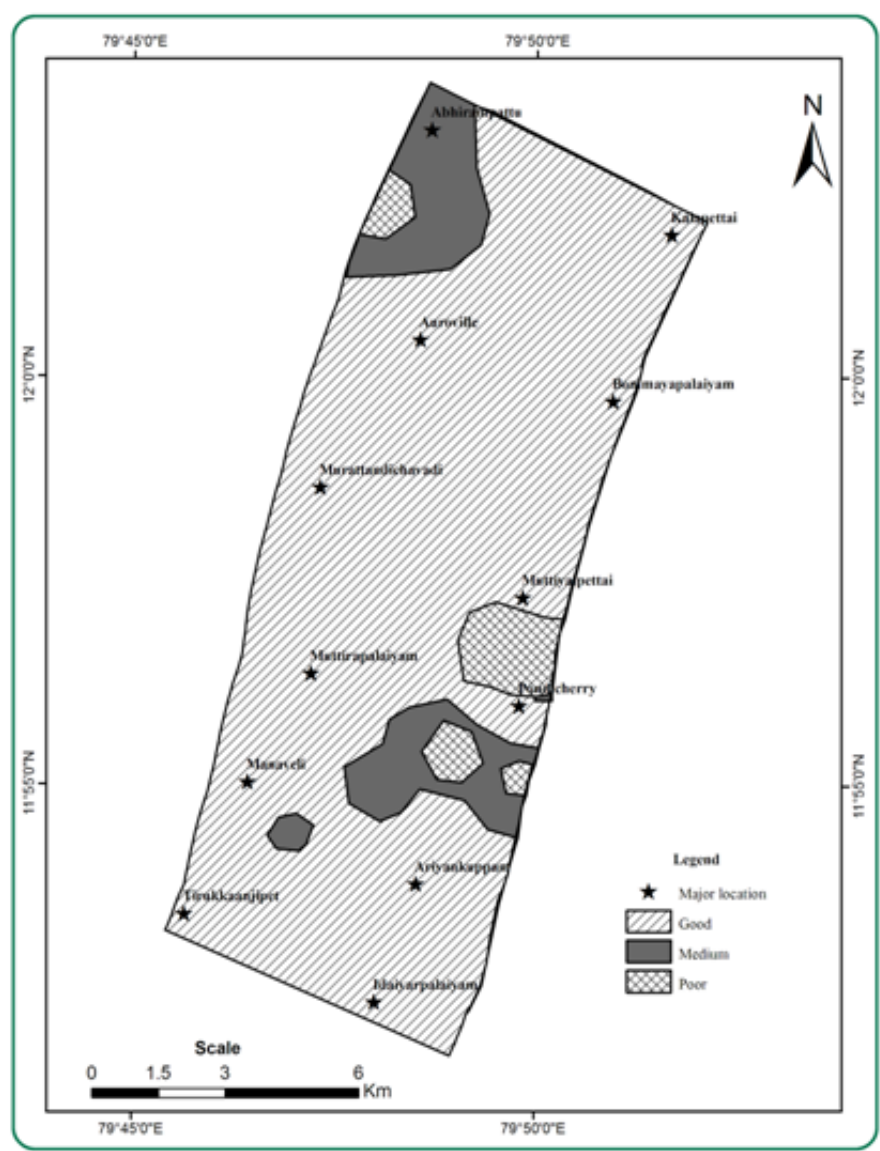

Fig. 2: Overlay Map of Ph., TDS, $\mathrm{Ca}, \mathrm{Mg}, \mathrm{Na}, \mathrm{K}, \mathrm{Cl}$ and $\mathrm{F}$ - Post Monsoon Season

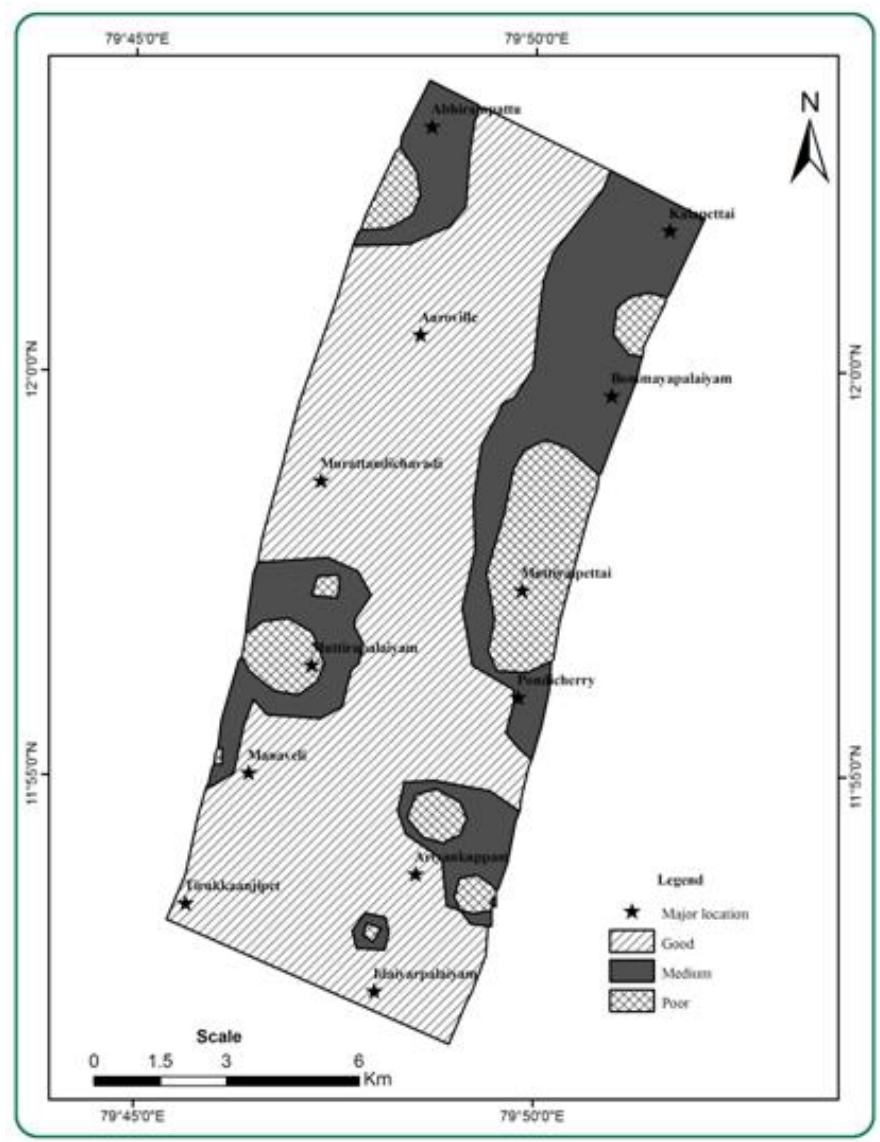

Fig. 3: Overlay Map of Ph., TDS, Ca, Mg, Na, K, Cl and F - Pre Monsoon Season 
Water According to World Health Organization (WHO 2004), although $\mathrm{pH}$ value usually has no direct impact on consumers, however, it is one of the most important operational water quality parameters.

As per WHO (2004) standard limit of 6.5 - 8.5, most of the groundwater samples fall the acceptable/desirable limit, and it is suitable for drinking, irrigation, industrial and domestic purposes except sample location numbers $6,10,19,26,27,28,30$, and 31 in the post monsoon season. However, in the pre monsoon season, all the samples fall the acceptable limit. Higher concentration of $\mathrm{pH}$ observed in northeast, middle and southern part of the study area during both seasons. The reason for increasing $\mathrm{pH}$ concentration in the coastal region could be related to the chloride in seawater or from marine clay.

Generally, total dissolved solids (TDS) are defined as the quality of dissolved material in water, and mainly depend on the solubility of rocks and soils contact in water. The TDS in the water samples during post and pre monsoon varied from 170 to $1148 \mathrm{mg} / \mathrm{l}$ and 126 to $951 \mathrm{mg} / \mathrm{l}$. The maximum value $(1148 \mathrm{mg} / \mathrm{l})$ noticed in the sample location no. 16 during both the seasons. According to Freeze and Cherry (1979), increased level of total dissolved solids is not only saline water intrusion in to the coastal aquifers, sometimes deep water condition dissolution of rock in ion particle mixed with fresh water in groundwater. Also, dissolution or weathering of the rock and solids and dissolving nature of lime, gypsum and other salts, when the source water passed over or percolates through them (Chebotarev, 1985 and Taghizadeh Mehrjardi et al., 2008). Low concentration of TDS (126mg/l) in the study area was related to the addition of fresh water and decrease in temperature that consequently reduced the evaporation rate. This was similar to the observation made by Suman MOR Et Al., (2006) in their study at Delhi on the assessment of groundwater quality near municipal solid waste land fill site. Higher concentration of TDS was observed in the east and southern part of the study area during post monsoon season.

Calcium $\left(\mathrm{Ca}^{+}\right)$is one of the most massive substances of the natural water and fifth abundant natural element. It is dissolved from soils and rocks and it is the major constituents responsible for hardness in water. The presence of calcium in drinking water is natural geological source, agricultural wastes, and industrial waste (Deshpande 2011). According to WHO standard (2004) the acceptable limit for $\mathrm{Ca}^{+}$for drinking water is $75 \mathrm{mg} / \mathrm{l}$ and $80 \%$ (28 samples) of groundwater samples fall the permissible limit. The calcium concentration during post monsoon varied from 16 to 143 $\mathrm{mg} / \mathrm{l}$ vide the sample location of $27 \& 16$, whereas the pre monsoon season ranged from 25 to $200 \mathrm{mg} / \mathrm{l}$ vide the sample location nos. 1,16 , and 29.

The principal sources of magnesium $\left(\mathrm{Mg}^{+}\right)$in the natural water are various kinds of rocks, sewage and industrial wastes are the important contributors (Deshpande 2011). Higher concentration of magnesium may contribute undesirable tastes to drinking water may have a laxative effect, particularly with magnesium sulphate concentrations above $700 \mathrm{mg} / \mathrm{l}$. The higher concentration of $\mathrm{Mg}^{+}$ was observed during the post and pre monsoon seasons were $97.47 \mathrm{mg} / \mathrm{l}$ and $44 \mathrm{mg} / \mathrm{l}$ vide the sample location of 16 and $1 \mathrm{re}-$ spectively. According to WHO (2004) standard, the desirable value is less than 30 and maximum permissible limit of $\mathrm{Mg}^{+}$is 30 - $150 \mathrm{mg} / \mathrm{l}$, whereas, the study area has 18 samples $(50 \%)$ falls desirable limit during post monsoon season. However, $74 \%$ of the samples (26 samples) fall the acceptable limit and $26 \%$ of the samples fall the maximum permissible limit during pre-monsoon in the study area.

The source of sodium $\left(\mathrm{Na}^{+}\right)$is derived geologically from leaching of deposit and decomposition of various minerals. $\mathrm{Na}^{+}$values varied from 7 to $119 \mathrm{mg} / \mathrm{l}$ and 5.6 to $147.5 \mathrm{mg} / \mathrm{l}$ at sample location nos. 3, 17 and 27, 10 during both seasons. According to WHO standard (2004), desirable limit is $50 \mathrm{mg} / \mathrm{l}$ and acceptable limit is $200 \mathrm{mg} / \mathrm{l}$, whereas, during post and pre monsoon desirable for 22 and 24 samples and acceptable for 13 and 11 samples fall the desirable limit. Spatial distribution of sodium during pre and post monsoon season a higher concentration was noticed at east and southern part of the study area.

Potassium $\left(\mathrm{K}^{+}\right)$occurs in various minerals, from which it may be dissolved through weathering processes. The concentration of potassium in groundwater during post monsoon season is high and it is varied from 1 to $32 \mathrm{mg} / \mathrm{l}$ at sample nos. $33 \& 24$. Similarly, in the pre monsoon season it is varied from 0.1 to $68.9 \mathrm{mg} / \mathrm{l}$ at sample no $6 \& 12$. According to WHO (2004) guidelines, the maximum desirable limit is $10 \mathrm{mg} / \mathrm{l}$ for drinking water and $21 \& 30$ samples fall this type of category for both the season.

The chloride $\left(\mathrm{Cl}^{-}\right)$concentration in the groundwater during post and pre monsoon season ranged from 81 to $407 \mathrm{mg} / \mathrm{l}$ and 44.31 to $487.43 \mathrm{mg} / \mathrm{l}$. The sample nos. of $5 \& 27$ is the lowest and 16 is the highest for both the seasons and the maximum concentration was observed at pre monsoon season. As per WHO (2004) standard, $\mathrm{Cl}^{-}$has desirable and acceptable limit is less than 250 and 250 $600 \mathrm{mg} / \mathrm{l}$. Generally, higher chloride content is attributed to the region where in high evaporation, enriched irrigation return flow and intensive irrigational activities and also due to high temperature and less rainfall. In addition, soil porosity and permeability also has a key role in building up the chloride concentration. Guo et al., (2003) states that, leaching of salt by water can also lead to higher concentration of chloride in groundwater. Due to higher concentrations of chloride in drinking water could cause a salty taste and have a laxative effect (Bhardwaj and Singh 2010). Chloride is a widely distributed element in all types of rocks in one or the other form. Its affinity towards sodium is high. The higher concentration of chlorides $(487.43 \mathrm{mg} / \mathrm{l})$ noticed at sample no. 16 can be attributed to the close proximity near to the sea and indicates that sea water intrusion could be possible as source of contamination.

Sulphate $\left(\mathrm{SO}_{4}^{-}\right)$, an anion formed by oxidation of the element sulfur, is commonly present in groundwater. According to Karanth (1987) sulphate content in groundwater is made possible through oxidation, precipitation, solution and concentration, as the water traverses through rocks. The concentration values varied from 2 to $21.9 \mathrm{mg} / \mathrm{l}$ and below detectable limit to $<7.1 \mathrm{mg} / \mathrm{l}$ in the study area and all the samples fall acceptable limit of $75 \mathrm{mg} / \mathrm{l} \mathrm{f}$ as per WHO (2004) standard for both the seasons.

During post and pre monsoon season, the ranges of bicarbonate $\left(\mathrm{HCO}_{3}\right)$ in the study area from 12 to $120 \mathrm{mg} / \mathrm{l}$ and 58.8 to $549 \mathrm{mg} / \mathrm{l}$. However, the maximum value was noticed at sample number 4 and 30 in the post and pre monsoon and overall the maximum concentration was noticed in pre monsoon season.

Fluoride $(\mathrm{F})$ is dissolved in low concentrations from rocks and soils, and traces of present in water and it is essential element for human (WHO 2004). Deficiency in drinking water $(<0.5 \mathrm{mg} / \mathrm{l})$ also leads to dental caries (Edmunds and Smedley 1996). Similarly, high intake of fluoride (over $1.5 \mathrm{mg} / \mathrm{l}$ ) results in physiological disorders, skeletal and dental fluorosis, thyroxine changes and kidney damages (Latha et al. 1999; ISI 1983). Hence, it is essential to have a safe limit of fluoride concentration is $<1.5 \mathrm{mg} / \mathrm{l}$ (WHO 2004) in drinking water. During both season, the fluoride values varied from 0.82 to $1.64 \mathrm{mg} / \mathrm{l}$ and 0.61 to $2.09 \mathrm{mg} / \mathrm{l}$ in the study area. The minimum and maximum values are noticed vide the sample nos. $37 \& 1$ in the post monsoon and $15 \& 25$ in the pre monsoon season.

The spatial distribution map prepared in GIS platform of groundwater quality parameters of $\mathrm{pH}, \mathrm{TDS}, \mathrm{Ca}^{+}, \mathrm{Mg}^{+}, \mathrm{Na}^{+}, \mathrm{K}^{+}, \mathrm{Cl}^{-}$, $\mathrm{HCO}_{3}^{-}, \mathrm{SO}_{4}^{-}$and $\mathrm{F}$. The overlay map of all the groundwater quality parameter for both seasons are classified into good (less vulnerable), medium and poor (high vulnerable areas) groundwater quality zones are demarcated as shown in Fig. 2 \& 3. The spatial extent of good, medium and poor groundwater quality zone areas is $118.93 \mathrm{~km}^{2}, 14.37 \mathrm{~km}^{2}$ and $6.70 \mathrm{~km}^{2}$ in the post monsoon season. Similarly, in the pre monsoon season, good groundwater quality zone areas are reduced from $118.93 \mathrm{~km}^{2}$ to $88.39 \mathrm{~km}^{2}$ and medium and poor areas are increased from $14.37 \mathrm{~km}^{2}$ to $33.75 \mathrm{~km}^{2}$ and $6.70 \mathrm{~km}^{2}$ to $15.86 \mathrm{~km}^{2}$ respectively. The poor groundwater quality 
areas are identified in between Muthialpettai and Pondicherry area in both seasons.

\section{Conclusion}

In this research, the groundwater samples were collected and analyzed the physical and chemical parameters from the coastal regions of parts of Tamilnadu state and Pondicherry Union Territory, India. The study investigates that the hydrochemistry of the coastal groundwater quality and its resources degradation is an issue of significant societal and environmental concern and could be the impact of sea water incursion on the groundwater in the study area. To meet the increasing demands of drinking groundwater, increase the resources by recharging through rainwater harvesting and to prevent by contamination.

\section{Acknowledgement}

We express our sincere thanks to DST, Government of India under the WAR for water programme for extending the financial support to carry out this work.

\section{References}

[1] American Public Health Association (APHA) (1995) Standard methods for the examination of water and waste water. American Water Works Association, Water Environment Federation, Washington.

[2] Bhardwaj V \& Singh DS (2010) Surface and groundwater quality characterization of Deoria District, Ganga Plain, India. Environmental Earth Sciences, doi: 10.1007/ s12665-010-0709-x.

[3] Carol E, MasPla J, Kruse E (2013) Interaction between continental and estuarine waters in the wetlands of the northern coastal plain of Samborombón Bay, Argentina. Appl Geochem. http://dx.doi.org/10.1016/j.apgeochem.03.006. (Online).

[4] CGWB Report (1993) Status of Groundwater Resources and Development in Pondicherry Region. Report of CGWB, Ministry of Water Resources, Govt. of India.

[5] Chebotarev (1985) Metamorphism of natural water in the crust of weathering, Geochem, Cosmochim, Acta, 8, 22-28

[6] Cruz JV and MO Silva (2000) Groundwater Salinization in Pico Island (Azores, Portugal): Origin and Mechanisms, Environmental Geology, Vol. 39, No. 10, pp. 1181-1189. doi: 10.1007/s002540000109.

[7] Deshpande SM, and Aher KR, (2011) Hydrogeochemistryand quality assessment of groundwater in Chikalthanaindustrial areaof Aurangabad, Maharashtra,India. Bionano Frontier, v.4(1),pp.157-16

[8] Dixit S, Gupta SK, \& Tiwari S, (2005) Nutrient overloading of a freshwater lake in Bhopal, India. Electronic Green Journal, (21), 2-6

[9] Edmunds WM, \& Smedley PL (1996) Groundwater geochemistry and health with special reference to developing countries. Geological Society Special Publication, 113, 91-105

[10]Freeze RA, \& Cherry JA, (1979) Groundwater. Englewood Cliffs: Prentice Hall

[11]Gimenez E, Morell I, (1997) Hydrogeochemical Analysis of Salinization Processes in the Coastal Aquifer of Oropesa (Castellon, Spain), Environmental Geology, Vol. 29, No. 1-2, pp. 118-131

[12]Gleeson T, Wada Y, Bierkens MFP, Van Beek LPH (2012) Water balance of global aquifers revealed by groundwater foot print. Nature 488:197-200

[13]Guler C, Kurt MA, Alpaslan M, Akbulut C, (2012) Assessment of the impact of anthropogenic activities on the groundwater hydrology and chemistry in Tarsus coastal plain (Mersin, SE Turkey) using fuzzy clustering, multivariate statistics and GIS techniques. J Hydrol; 414 415:435-51

[14]Guo HM, Wang YY, Grigory M.S \& Yan SL (2003) Natural occurrence of arsenic in shallow ground water shunyian, Datong basin China. J. Environ Scien and Hlth, Part A 38 (11), 2565-2580

[15]ISI, (1983) Indian Standard Specification for drinking water. IS: 10500. New Delhi: Indian Standard Institutions.

[16]Karanth KR (1987) Groundwater Assessment, development and management. Tata Mcgraw Hill, New Delhi, pp 720.1

[17] Kim JH, Kim RH, Lee J, Chang HW, (2003) Hydrogeochemical characterization of major factors affecting the quality of shallow groundwater in the coastal area at Kimje in South Korea. Environ Geol; 44:478-89
[18]Latha SS, Ambika SR \& Prasad SJ (1999) Fluoride contamination status of groundwater in Karnataka. Current Science, 76(6), 730-734

[19]Leung CM, Jiao JJ, Malpas J, Chan WT, Wang YX, (2005) Factors affecting the groundwater chemistry in a highly urbanized coastal area in Hong Kong: an example from the mid-levels area. Environ Geol; 48:480-95.

[20]Olowokudejo TA (2007) Targeting of high quality groundwater in the province of Vientiane, Laos, PDR. M.Sc Thesis, Lulea University of Technology, Sweden, pp 55

[21]Rai VK (2004) Suitability of surface and groundwater for irrigation: a case study. National Geographical Journal, India. VHU (UP) 50:8394

[22]Suman Mor, Khaiwal Ravindra, Dahiya, R.P. \& Chandra A (2006) Leachate Characterization and assessment of ground water pollution near municipal solid waste landfill site. Environmental monitoring and assessment, 118, 435-456

[23] Taghizadeh Mehrjardi R, ZareianJahromi M, Mahmohdi, S \& Heidari (2008) Spatial Distribution of ground water quality with geostatics (1): 09-17

[24]Todd D K 1980 Groundwater hydrology. John Wiley and Sons, New York

[25]Wang Y, Jiao J J (2012) Origin of groundwater salinity and hydrogeochemical processes in the confined Quaternary aquifer of the Pearl River Delta, China. J Hydrol, 438-439: 112-24.

[26]WHO, (2004) Guidelines for drinking water quality. World Health Organization. 